
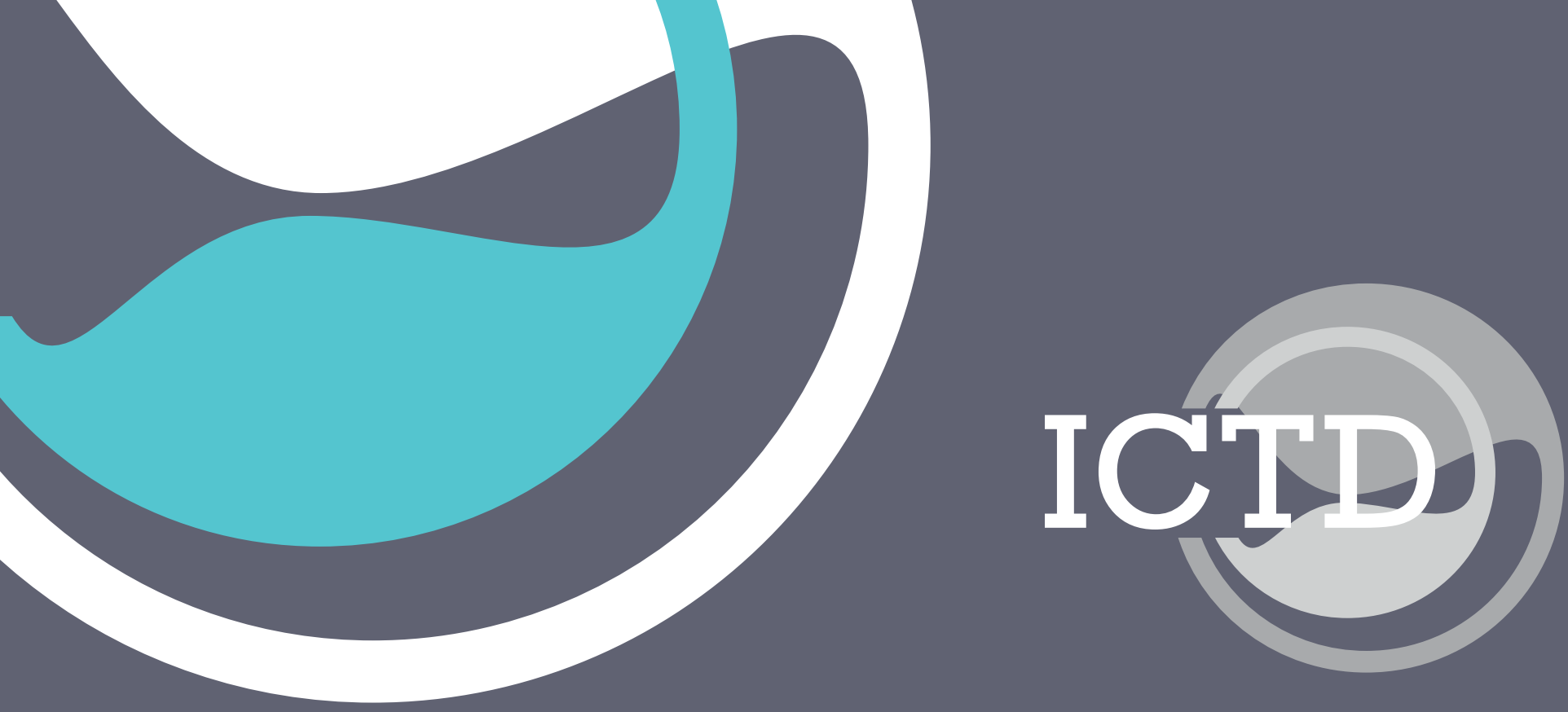

Working Paper 120

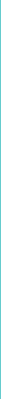

Taxation and Customs Reforms in Fragile States: Between Bargaining and Enforcement

Thomas Cantens and Gaël Raballand May 2021 
ICTD Working Paper 120

Taxation and Customs Reforms in Fragile States: Between Bargaining and Enforcement

Thomas Cantens and Gaël Raballand

May 2021 
Taxation and Customs Reforms in Fragile States: Between Bargaining and Enforcement Thomas Cantens and Gaël Raballand

ICTD WORKING PAPER 120

First published by the Institute of Development Studies in MAY 2021

(C) Institute of Development Studies 2021

ISBN: [978-1-78118-804-0]

DOI: [10.19088/ICTD.2021.009]

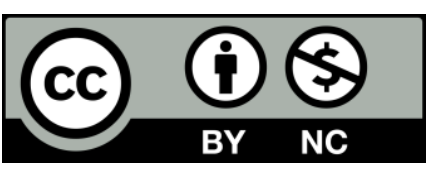

This is an Open Access paper distributed under the terms of the Creative Commons Attribution Non Commercial 4.0 International license, which permits downloading and sharing provided the original authors and source are credited - but the work is not used for commercial purposes. http://creativecommons.org/licenses/by-nc/4.0/legalcode

\section{Available from:}

The International Centre for Tax and Development at the Institute of Development Studies, Brighton BN1 9RE, UK

Tel: +44 (0) 1273606261

Email: info@ictd.ac

Web: www.ictd.ac/publication

Twitter: @ICTDTax

Facebook: www.facebook.com/ICTDtax

IDS is a charitable company limited by guarantee and registered in England

Charity Registration Number 306371

Charitable Company Number 877338 


\section{Taxation and Customs Reforms in Fragile States: Between Bargaining and Enforcement}

Thomas Cantens and Gaël Raballand

\section{Summary}

This paper explores why taxation reforms are so different in fragile states, the conditions in which they occur, and what can be done to make these reforms more successful - including contributing, whenever possible, to state-building. Based on extensive engagement and fieldwork in the Sahel and other regions in sub-Saharan Africa (including Central and West Africa, and Somalia), this multidisciplinary paper builds on findings regarding taxation history in Africa, as well as existing research in anthropology and political economy. The paper explains why several prerequisites, such as state legitimacy or a centralised taxation power, are not present in most countries affected by fragility, conflict and violence (FCV), and, thus, why in many cases enforcement is impossible. It also explores the continuity between the institutions of colonial administrations and current tax and customs administrations, including why major changes cannot be expected in a short period of time. The level of taxation in FCV countries is mainly the result of bargaining processes between powerful actors.

Keywords: customs; taxation; fragile and conflict-affected states; state legitimacy; informal trade; historical continuity.

Thomas Cantens is a French customs officer, advisor at the Niger customs based in Niamey, and associate researcher and lecturer in social anthropology and ethnology at Clermont Auvergne University (thomas.cantens@douane.finances.gouv.fr). He was earlier advisor to several Directors General of Customs in Mali and Cameroon, and worked as head of the research unit at the World Customs Organization.

Gaël Raballand is lead public sector specialist at the World Bank Group (graballand@worldbank.org). He has been involved in customs reforms for the World Bank in almost 30 countries, with a focus on low-income countries. 


\section{Contents}

Summary 3

Acknowledgements $\quad 5$

$\begin{array}{ll}\text { Acronyms } & 5\end{array}$

1 Introduction, and what is at stake? 6

2 Why taxation in FCV countries departs from the traditional model of taxation

2.1 Weaker state legitimacy 9

$\begin{array}{ll}2.2 & \text { The weight of colonial legacy } \\ & 11\end{array}$

2.3 Limits of state monopoly on taxation 12

2.4 Regressive tax systems: taxation of the poor, victims of the bargaining process 13

3 Improving state-building and taxation in FCV countries at the same time: under which political conditions?

3.1 Revisiting the fiscal contract: taxing in the name of something rather than for something 14

3.2 Is local taxation a realistic part of the solution? 15

3.3 Customs revenue, a major source of revenue in FCV countries 16

$4 \quad$ Linking policy and technique: measures applied to customs 17

4.1 Use data and develop data analytics to make taxation more transparent 18

$\begin{array}{lll}4.2 & \text { Combine anti-fraud and anti-corruption efforts } & 18\end{array}$

4.3 Deploy customs in fragile borderlands to restore the presence of the state 19

$\begin{array}{lll}4.4 & \text { Technical assistance on the ground } & 20\end{array}$

$5 \quad$ Concluding remarks $\quad 21$

Annex 1 Share of tax revenue collected by customs 23

Annex 2 Fighting against fraud and corruption - some technical measures
applied to customs

$\begin{array}{ll}\text { References } & 25\end{array}$

Figures

Figure $1 \quad$ Conflict states vs. non-conflict states (regional average, 2020) 9

Figure 2 SSA: High- vs. medium-intensity conflict states (2020) 10

Figure $3 \quad$ MENA: High- vs. medium-intensity conflict states (2020) 10 


\section{Acknowledgements}

The authors wish to thank the customs administrations of Niger and Somalia for their support, Roel Dom, Olav Lundstøl, Mick Moore, Mariya Polner and one anonymous referee for their very helpful comments, and Raul Junquera-Varela for guidance.

\section{Acronyms}

$\begin{array}{ll}\text { ATI } & \text { Addis Tax Initiative } \\ \text { FCV } & \text { Fragility, conflict and violence } \\ \text { IMF } & \text { International Monetary Fund } \\ \text { NGO } & \text { Non-government organisation } \\ \text { OECD } & \text { Organisation for Economic Cooperation and Development } \\ \text { UN } & \text { United Nations } \\ \text { WCO } & \text { World Customs Organization } \\ \text { WTO } & \text { World Trade Organization }\end{array}$




\section{Introduction, and what is at stake?}

In the last decade, African authorities and the international community have called for support to increase taxation capacity in order to reduce reliance on aid flows. This commitment to support tax administrations was reflected in the 2015 Addis Tax Initiative (ATI), which advocated 'to double assistance to developing countries in order to strengthen their tax systems and administrations' by the year 2020 (IMF 2017: 6). Increasing domestic resource mobilisation is even more salient for state-building in fragile states, in terms of providing costly services to citizens, including security, across national territory. There is a rich literature (Acemoglu and Robinson 2012; Besley and Persson 2009) arguing that robust and inclusive fiscal institutions are essential for state-building and economic growth. This is not the situation in fragile states.

Despite the critical importance of taxation and revenue collection for fragile states, it has been particularly challenging to record sustainable progress given the functioning of those states, economies and societies. The impact of taxation reforms in fragile states has been particularly disappointing in recent decades. The ratio of domestic revenue to gross domestic product is lower in FCV countries than in other developing countries (Akitoby et al. 2020; Isar 2020). Moreover, tax reforms in FCV countries have a higher likelihood of failing, and also lack sustainability (Drummond et al. 2012). Even if revenue collection rebounds after a conflict, it is usually insufficient to offset the initial decline. Finally, taxation is rarely considered a major factor in crisis prevention or in post-crisis situations, although it can play a role in both contexts.

This paper explores why taxation reforms are so different in FCV countries, the conditions in which they occur, and what can be done to make these reforms more successful - including contributing, whenever possible, to state-building.

There are case studies on some countries, such as the International Monetary Fund (IMF) papers on Somalia (Kalyundu and Norregaard 2020), and some papers focusing on technical aspects of taxation in fragile states (IMF 2017). However, to our knowledge, there are very few papers on taxation in fragile states combining technical, historical and political economy aspects - one of the few exceptions being Fjeldstad et al. (2018).

To fill this gap, this paper aims to demonstrate the benefits of a multidisciplinary approach for tackling taxation reforms, combining findings from anthropology, history and political economy.

The paper synthesises key ideas and arguments based on many years of experience and policy engagement in this area in the Sahel and other sub-Saharan African regions since 2016 - including in regions where the state's presence is challenged by armed groups, particularly Somalia and the Sahel. ${ }^{1}$

The paper also explores the role of historical continuity between the institutional set-up of colonial administrations, and current tax and customs administrations. All tax and customs administrations, including those of fragile states, now share the same conceptual and technical framework, due to common global norms developed by international organisations. ${ }^{2}$

e.g. the state presence is challenged by armed groups in the following countries: Burkina Faso, Chad, Iraq, Libya, Mali, Niger, Nigeria, Somalia and Sudan, as well as Syria, Central African Republic (CAR), Democratic Republic of the Congo (DRC) and Yemen.

International organisations having an impact on taxation norms include the World Customs Organization (WCO), the World Trade Organization (WTO), and the Organisation for Economic Cooperation and Development (OECD). The WCO is in charge of disseminating norms and standards in customs procedures through international agreements. 
The progressive standardised approach since the 1950s tends to blur the long-term historical process of state-building, and the role of taxation in it. In addition, studies on taxation in developing countries assume a sharp break between colonial and post-colonial periods, and rarely address historical continuity (Andersson 2015). However, there is no historical break in the institutions of taxation, even for countries that were colonised. In China, for example, Jin (2018) shows that the colonial past of customs administrations had a long-term impact on local economic development. Understanding historical continuity is critical for raising awareness of why major changes cannot realistically be expected in a short period of time.

This paper advocates taking politics more into account with taxation reforms. The level of taxation is mainly the result of bargaining processes between powerful actors. ${ }^{3}$ Reforming taxation in such contexts, therefore, assumes two shifts in the ideological status of the state when its legitimacy is at stake. First, taxes should be considered as instruments of social change, and tax options should be primarily evaluated in terms of their likely political impact, including the circulation of wealth within society (Fairfield 2015). This approach differs from the quantitative approach to taxation, which would favour tax measures in developing countries that generate the most revenue. ${ }^{4}$ Second, if the state should be rebuilt or consolidated, it must be recognised that the state is first and foremost coercive by nature. Putting the political economy of taxes back at the heart of taxation in fragile states assumes that the state is a coercive power, and that negotiation of taxes is a power relationship. Therefore, political economy considerations are crucial, and need to be included in the design of any taxation reform.

The common model for taxation is built on three critical tenets that are not always explicit:

- general acceptance of taxation coupled with strong state legitimacy (with a subsequent tax base);

- a largely centralised and transparent revenue collection; and

- a system of formalised revenue collection.

In developing countries, where taxation systems are less efficient, this agreement takes a 'reciprocalist' ${ }^{5}$ form that is explicitly summarised in the 2015 ATI: taxes - domestic resource mobilisation - should fuel economic development. Reciprocity, a major source of trust (Levi 2003), is considered crucial to reinforce government accountability vis-à-vis citizens (OECD 2014). As a fiscal contract between the people and the state, it should reduce corruption, and, theoretically, generate a virtuous tax bargaining process (Brautigam et al. 2008). In FCV countries, where the state has partially lost its monopoly on the means of violence, the reciprocity of the fiscal contract is usually considered critical (Mansour and Schneider 2019).

Deriving from such a model, the usual objectives for low-income countries are to:

- broaden the tax base, mainly by formalising the informal sector, which leads to the 'registration obsession' (Moore 2020);

- move from trade taxes to domestic resources, that is, the 'tax transition' concept that consists of limiting tariffs and duties, strengthening trade facilitation measures and developing internal tax collection, including VAT (Chambas 2005);

Although the domain of internal taxation is less normative, 'global' tools like the Tax Administration Diagnostic Assessment Tool (TADAT) are widely used by international organisations to assess tax systems in developing countries.

3 It concurs with Prichard's (2019) assessment that taxation is 'fundamentally political'.

$4 \quad$ The efficiency of militant groups in enforcing collection of revenue is sometimes highlighted by donor representatives, and shows how revenue collection may become an end in itself - no matter how or by whom it is generated.

$5 \quad$ The authors thank Mick Moore for suggesting this neologism. 
- facilitate payment by taxpayers, particularly larger ones, by developing large taxpayer units (Vehorn 2011; Macedo 2011).

The scope of this paper has two limitations. First, it addresses taxation in the context of fragility, not necessarily in FCV countries as listed by international organisations. Although the definition of fragility remains contested to some degree, it has moved from a rather narrow and technical definition, ${ }^{6}$ to a more discrete and multidimensional approach that better takes into consideration fragility in middle-income countries, the conflict intensity dimension, and spatial dynamics. ${ }^{7}$ Using the most recent classification of fragility and conflict situations for World Bank Group engagement, we focus on countries or areas with highintensity conflicts ${ }^{8}$ and medium-intensity conflicts. ${ }^{9}$ Our focus is rather similar to that of Fjeldstad et al. (2018: 11), as it involves the same set of countries: 'fragile states are, [...], states whose monopoly on violence is either undermined or at considerable risk of being undermined'. More concretely, it means that in those countries, at local level, outside the national and regional capitals, civil servants (including police, customs officers and tax collectors) find it difficult to operate normally. The geographical limitation of fragility, including within the national territory, is important - as demonstrated by the collapse of the Malian state in 2013 due to a 'fragile' northern region.

Second, the technical recommendations mainly focus on customs administrations, because customs are, de facto, the key player in state (re)building in fragile contexts. With the emergence of the concept of fiscal transition, and free trade agreements between African countries and the United States (US) and European Union (EU), the role of customs administrations in revenue collection was expected to decrease and slowly disappear. However, customs have remained central to taxation in FCV countries, and this is now widely acknowledged (IMF 2017). Indeed, goods are essentially easier to tax than people. ${ }^{10}$

The paper is structured as follows. Section 2 highlights why the main tenets of tax and customs are not largely applicable to most FCV countries. It addresses the extent to which this model is impacted by the weak legitimacy of the state, insecurity and fragility, as well as the weight of historical continuity. Section 3 describes the conditions under which taxation and state-building can be reconciled to improve revenue collection, highlighting the role of customs, and questioning the impact of local revenue collection on social contracts. Section 4 proposes some policy recommendations, taking into consideration the political economy dimension, with a focus on customs.

\footnotetext{
$6 \quad$ This definition relies on a combination of a low Country Policy and Institutional Assessment (CPIA) rating (as a proxy for poor governance) and the existence of United Nations (UN) peacekeeping missions.

$7 \quad$ The causes and effects of fragility can be very different, such as between Zimbabwe and Somalia. Fragility may also be intra-state (Kenya, Nigeria) or country-wide.

$8 \quad$ High-intensity conflict countries include Afghanistan, the Central African Republic, Libya, Somalia, South Sudan, the Syrian Arab Republic, and the Republic of Yemen.

9 Medium-intensity conflict countries include Burkina Faso, Burundi, Cameroon, the Democratic Republic of Congo, Iraq, Mali, Niger, Nigeria and Sudan.

10 The impact of customs collection on the fiscal contract is discussed below.
} 


\section{Why taxation in FCV countries departs from the traditional model of taxation ${ }^{11}$}

There is a common assumption that a modern taxation system relies on a social contract of taxes in exchange of services provided by the state, and a political process of negotiation between the rulers and the people (Tilly 2009). This model is mostly inspired by Western fiscal state-building, and is technically driven by a reciprocalist approach that does not fit well within the context of fragility.

State legitimacy, or a centralised taxation power, are not present in most FCV countries. However, public administrations and experts still usually address taxation reforms from a technical perspective, or, at best, assume that a virtuous circle should exist between taxation, representation and accountability. In numerous cases, this does not and cannot occur.

\subsection{Weaker state legitimacy}

State legitimacy is relatively weaker in conflict-affected countries than in non-conflict-affected countries, especially for countries facing high-intensity conflicts (Figure 1). More specifically, apart from three Sahelian countries (Burkina Faso, Mali and Niger),,$^{12}$ conflict-affected countries in Middle East and North Africa (MENA) and sub-Saharan Africa (SSA) have a much lower level of state legitimacy (Figures 2 and 3).

Figure 1 Conflict states vs. non-conflict states, (regional average, 2020)

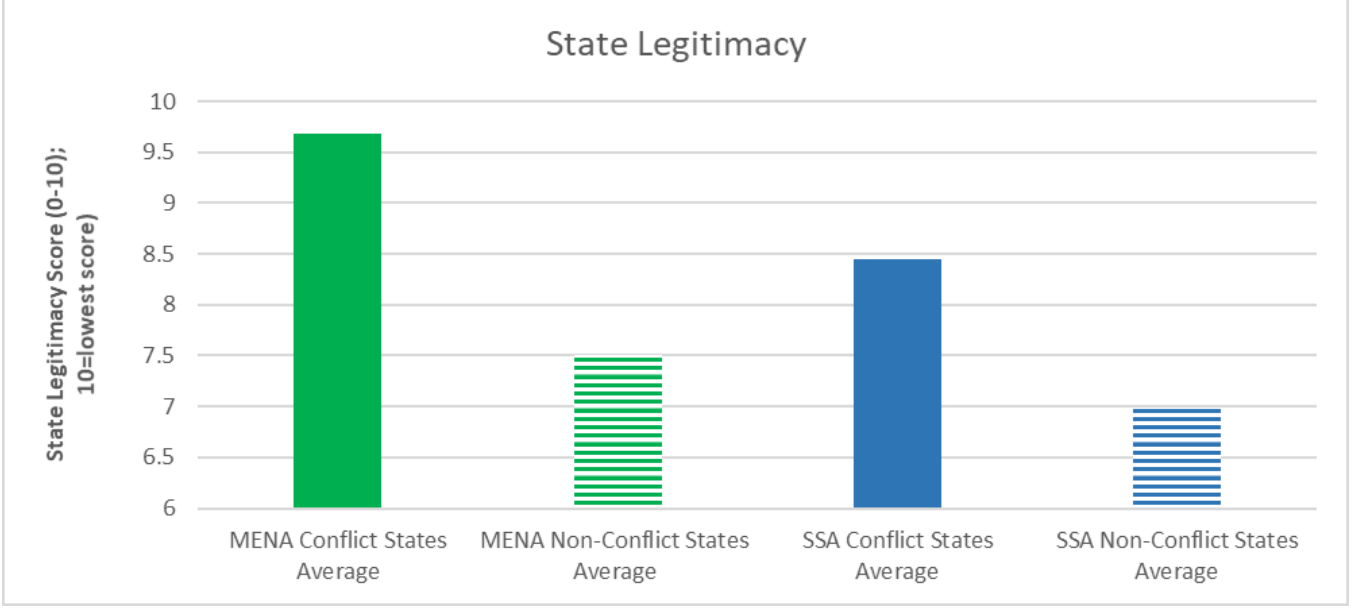

Source: Fragile States Index, The Fund for Peace. ${ }^{13}$

\footnotetext{
11 A number of features, such as the problem of a regressive tax system and poor bargaining power of tax administrations, is also common with low-income countries. However, the impact of the conflict dimension in most FCV countries implies some specificities in terms of taxation by armed groups or low state legitimacy.

12 These three countries are also outliers in terms of revenue collection (Figure 1).

13 See https://fragilestatesindex.org/indicators/p1/ for a definition of the State Legitimacy indicator. The indicator looks at the population's level of confidence in state institutions and processes, and assesses the effects where that confidence is absent, manifested through mass public demonstrations, sustained civil disobedience, or the rise of armed insurgencies. Data comes from three main streams: pre-existing datasets, content analysis and qualitative expert analysis, and is triangulated and subjected to critical review to obtain final scores for the Index.
} 
Figure 2 SSA: High- vs. medium-intensity conflict states (2020)

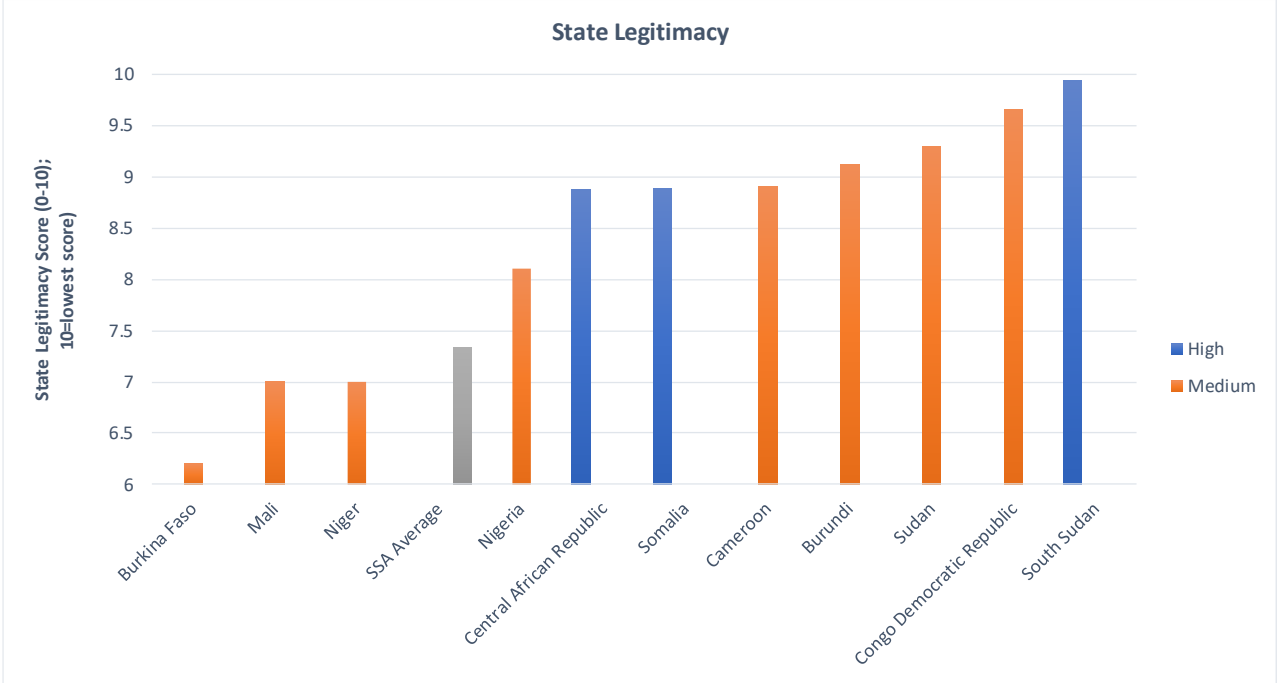

Source: Fragile States Index, The Fund for Peace (see https://fragilestatesindex.org/indicators/p1/).

Figure 3 MENA: High- vs. medium-intensity conflict states (2020)

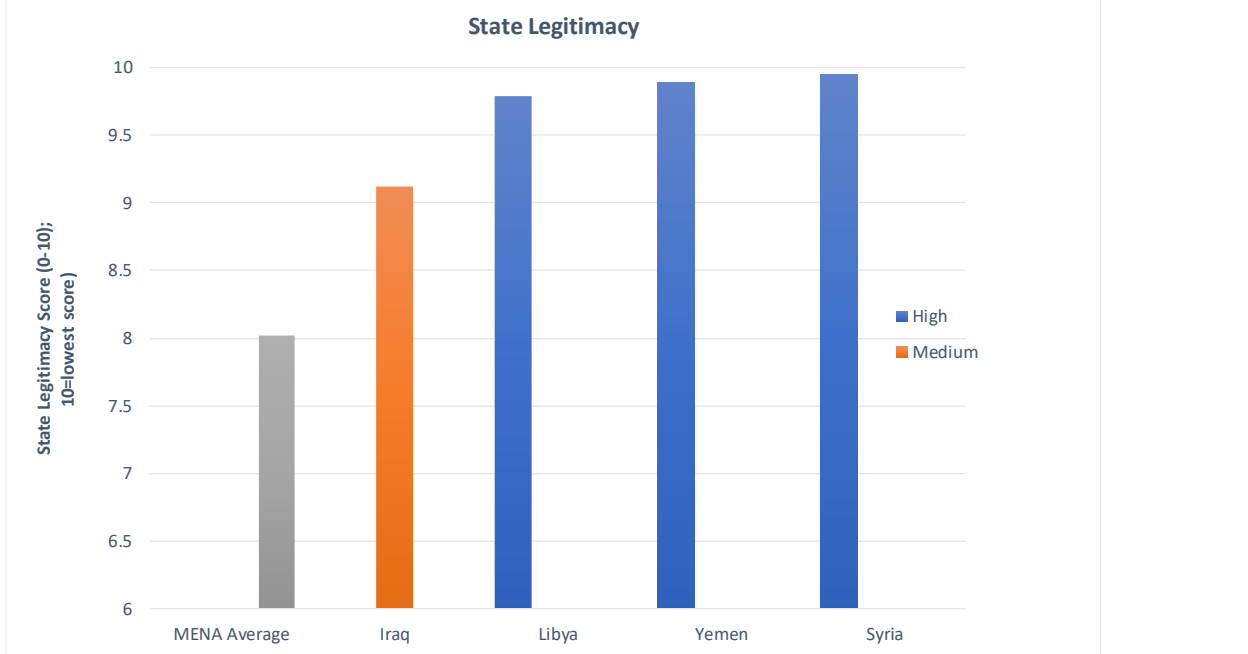

Source: Fragile States Index, The Fund for Peace (see https://fragilestatesindex.org/indicators/p1/).

This lack of confidence in national institutions and processes in FCV countries may have many different causes. These can include: the absence of state services in many parts of the territory, as well as corruption of civil servants (although this feature is not specific to FCV countries); behaviour of state security agencies that is sometimes violent or leads to racketeering of the local population; and overreliance on donors.

Tax acceptance to (re)build a state does not necessarily appear to be relevant to many citizens in FCV countries. In many cases, citizens expect service delivery, which may not necessarily be provided by state actors. For example, national and international nongovernmental organisations (NGOs), private companies or even armed groups can provide these services. In Somalia, some militias have exercised police activities in parts of the territory (Day 2020). Some militias in northern Mali have been institutionalised and have supported the actions of the army (Cantens and Raballand 2016). The presence of foreign armies and UN peacekeeping missions, as well as the large share of grants in the national budget and their visibility, globally impact the legitimacy of the state. Moreover, the projectbased approach adopted by donors can lead to two parallel state services - one driven by 
the formal state apparatus, and one driven by donors (Blundo 2011). In this context, all nonstate processes and actors contribute to building the image of a state that may be the weakest public actor in some parts of the territory.

\subsection{The weight of colonial legacy}

The process of reconciling state-building and a modern taxation system faces two main colonial legacies that may be more important in reforms of FCV administrations than in other developing countries.

The first colonial legacy is the relationship between state presence and profitability, particularly tax profitability. Contemporary deployment of the fiscal state over territory still follows a historical legacy: centralised taxation focusing on the profitability of the territory. Remote areas that were largely unoccupied by the state during colonial times remain the same today.

For example, in Niger, colonisation first spread along the Niger river in regions that had abundant resources, as well as along the border with British colonies - to consolidate the French presence. Taxation in these borderlands was less coercive - so that people would not cross the borders and flee from territories under French rule (Lefebvre 2015). The profitability criteria of territories was also important when choosing where to deploy the state presence. The explanatory memoranda of colonial budgets expressed the constant concern of colonial administrators to collect as much as possible in revenue, as well as the ability to grow economically in areas they were administering. ${ }^{14}$

The emergence of the fiscal state was not simultaneous in many colonies. The focus was on the coast - specifically, in the main ports and along the main transport corridors. From the beginning of the sparse French occupation in 1890, Niger remained a military territory, ruled by the colonial authorities in Dakar, Senegal, until 1922. Customs was created in 1937 in Niger, and in 1862 in Senegal. More generally, in French West African colonies the coastal countries benefited from customs administrations, whereas the hinterland countries were subject to military authority for a much longer time, with more limited revenue collection and less investment in tax collection.

This was done at the expense of more remote regions, usually corresponding to some contemporary border regions - for instance in the Sahel, where terrorist groups have been growing and operating since 2010. Examples include northern Mali, northern Nigeria, northern Cameroon, and Darfur in Sudan. Armed groups emerged in those areas and still operate, resulting in a concentration of security incidents. In 2020 in Niger, for instance, more than half of incidents with armed groups took place within 20 kilometres of a border. ${ }^{15}$ The geographic evolution of armed groups and trade flows is not always predictable, making profitability difficult to calculate. As an example, in 2019 Nigeria closed its borders, forcing traffic with Niger to transit through the port of Lomé and then up to Niger by a route rarely used, causing an increase of more than 20 per cent in traffic to a few Niger customs offices bordering Burkina Faso ${ }^{16}$ - an area of operations for jihadist groups.

The second historical legacy is the importance of power relationships or rapport de force in taxation. As a colonial legacy, many customs administrations in francophone Africa are comprised of armed uniformed officials. This confusion between collection of taxes and the

\footnotetext{
14 e.g. see the Budget du Territoire militaire du Niger, from 1913 to 1920, and Andersson (2015).

15 Computation by authors based on incidents recorded by the Armed Conflict Location and Event Data Project (www.acleddata.com).

16 Data source : Niger customs.
} 
use of force has historical roots. During colonial times, taxes paid by local populations were based on a power relationship. Traditional chiefs were mobilised as tax collectors. The first colonial customs officers were military auxiliaries. In Niger the tax was collected by meharistes (military patrolling on camels), who were permitted to levy in-kind taxes in nomadic camps, thus meeting their own food supply needs while on patrol. This proximity between the army and customs is still in force today, and is part of what Blundo and Glasman (2013) call 'bureaucrats in uniform'. In many francophone sub-Saharan countries, customs are paramilitary: customs recruits have to go through a six-month training period in the army. In Togo, the customs headquarters building was adjacent to the army building until November 2020, despite the fact that customs had merged with the tax administration under the auspices of the revenue authority back in 2012.

In the Sahel, in villages close to the borders, customs officials may be attacked or threatened. In 2006, smugglers poured gasoline on a customs officer in Maroua (Northern Cameroon), and threatened him with a matchstick. In 2007 in Kousseri (a region that has been under threat from Boko Haram since 2011), customs officers and their families were forced to hide in the military camp, because people burnt down their homes when a fuel trafficker died in a motorcycle accident during a customs chase. In Niger, the hostility of the villagers regularly turns violent when customs officials consider seizing or interrupting fuel trafficking with Nigeria.

The effects of this perceived link between tax and military forces, and the trauma it caused for local policymakers in the post-colonial period, should be further examined, given the longlasting crisis for societies that were subjected to authoritarian social transformation through taxation. The fragility of states cannot be fully explained by the historical conditions of their emergence - but historical factors allow for a better understanding of the current situation, and should help to put the building of the fiscal state into a long-term perspective, linking the monopoly on taxation and unification of the country.

\subsection{Limits of state monopoly on taxation}

State legitimacy is ultimately weakened by taxation imposed by armed groups. In Afghanistan, the Taliban set up a 'Stones Commission' taxing mining (Dupée 2017), and would tax the export of drugs (Peters 2009). The Islamic State of Iraq and Syria implemented an effective taxation system on cross-border trade, and even issued paperwork to ensure traders were not taxed twice (Blannin 2017). In Somalia, Al-Shabab has been able to tax goods en route to or at the ports (Abshir et al. 2020; World Bank 2020). In Lake Chad, Boko Haram imposed taxes on traders and cattle owners (Cantens 2019). There are many other examples. In general, armed groups have higher coercion and enforcement powers - they may even have more predictable administrative processes than tax and customs services (Cantens 2019).

Tax competition between state and non-state actors has important consequences for functioning at the local level. Local taxation is crucial for providing security in FCV countries, especially when only limited support is provided by national authorities. For instance, in the northern part of the Central African Republic, a head of the Customs Bureau dedicated a part of the revenue collected to pay for militia protection against armed groups. In Somalia, the government of Jubbaland needed customs revenue to pay security forces to ensure the security of Kismayo against armed groups.

Customs and tax offices that are located outside the capital often have a certain autonomy in connection with the local representative of the state (Cantens 2012). For example, in Mali, the Timbuktu customs collector did not remit revenue he collected to the central level. When 
the subject was raised in a meeting with the Director General of Customs in Bamako, the regional director, who was stationed in Gao, justified the withholding of revenue based on the lack of fuel, and the trade-off between the effort required to go to Timbuktu to obtain the revenue and the amount of revenue itself.

This relative autonomy may lead to competition between customs offices within the same country to attract importers and meet revenue targets more quickly (Cantens 2012). In addition, in remote areas where there are few banking services local authorities must pay their providers in cash. Customs and tax revenue represent the only source of cash that can be easily accessed by local authorities whose national budget allocation payments are delayed or not transferred.

\subsection{Regressive tax systems: taxation of the poor, victims of the bargaining process}

Negotiating taxes entails a power relationship everywhere, including in rich countries. In many developing countries, tax and customs administrations often prefer to negotiate taxes rather than directly face fraud that they are unable to stop, due to lack of resources, difficulty in identifying potential taxpayers, accessing border zones, complexity in assessing the value of certain goods or the wealth of some large taxpayers, as well as occasional lack of political support. Thus, for instance, customs administrations prefer to agree with importers on minimum values for some revenue-generating goods or on some flows, like containers filled with miscellaneous goods from China (Cantens 2013). The threat of import strikes ${ }^{17}$ - the consequences of which are terrible for cash-strapped governments - allow business elites or highly organised groups to negotiate taxes either directly with revenue administrations or with governments. ${ }^{18}$

The existing tax bargaining process has two consequences in FCV countries. The balance of power between the state and economic elites is largely to the detriment of the state, and in favour of the wealthiest economic actors. ${ }^{19}$

Power asymmetry exists with a very high concentration of taxpayers. Taxation in Somalia and Niger is spatially and socially concentrated, in some cities and among a few dozen taxpayers. For instance, 20 traders account for 50 per cent of customs revenue in Mogadishu, and in 2020 in Niger 23 of the 2,772 importers accounted for more than 50 per cent of taxes and duties. ${ }^{20}$

Taxation therefore becomes regressive, in the sense that, relatively, it is the poorest who bear the burden because their negotiating power is the weakest. In the 1980s and 1990s, the tax system reform - tax transition - was meant to lower tax pressure on trade and increase domestic revenue by implementing VAT, which impacts everybody with the same rate. Fjeldstadt et al. (2018) rightly note that more efficient tax systems can make the poor poorer if equity is not a priority in tax policy and administration.

Taxing the informal sector, which includes small and medium enterprises (SMEs) or small and petty traders, is usually an explicit objective for policymakers and tax administrators

\footnotetext{
17 Import strikes are a refusal to import goods to stop payment of taxes.

18 In Togo in 2011, 'Mama Benz,' large informal traders, had threatened authorities with a strike on imports if flat taxes on their imports were not set at the level they had decided, which was very low compared to the value of goods.

Even in non-fragile developing countries, large taxpayers benefit from special conditions during the tax negotiation process. The OECD even recommends negotiating with wealthy taxpayers because they have more diversified and complex assets (OECD 2009).

20 Source: Niger customs data (authors' calculations).
} 
when the taxation of other areas, such as real estate, is poorly developed or enforced. Implicitly, it is understood that the poor and informal sector should be potentially taxed because they represent millions of individuals with low bargaining power. Taxation of this sector could bring more revenue than focusing on wealthy taxpayers, who have more bargaining power. It may however lead to limited increased revenue at the end of the process, especially when tax administrators face widespread corruption, and the informal sector is tolerated with limited taxation.

\section{Improving state-building and taxation in FCV countries at the same time: under which political conditions?}

\subsection{Revisiting the fiscal contract: taxing in the name of something rather than for something}

There are two main caveats when applying the security-versus-tax contract in FCV countries. First, policy recommendations often assume the existence of the fiscal state granted by people. However, societies can organise themselves separately and independently of national states and bureaucracies, especially at the local level. State avoidance and an informal economy do not necessarily lead to the disorganisation of societies (e.g. Ayadi et al. 2013 on Tunisia). Moreover, anthropologists, like Pierre Clastres (1974) and James Scott (2009), have shown how societies can resist or avoid the emergence of monopolistic forms of power - including the state.

Second, paying taxes and being provided with security raises a serious problem with timescale. On the one hand, large economic actors do not necessarily pay taxes but a 'tribute' to the state. In all the interviews conducted with large traders, very few challenged the state's legitimacy to tax them. For instance, a wealthy trader recognised that he had to pay taxes, but he calculated how much state revenue should be collected by assessing what the head of state needed for his travel and army.

On the other hand, economic elites ensure their own security by contracting with local groups at a much lower price than their own contribution to the state. ${ }^{21}$ When interviewed on the need to pay taxes for security, an importer responded that he paid US\$1 million in duties and taxes per year to the government, but only US\$50 per month to a group of young people in his neighbourhood who keep his property safe.

There cannot be a transaction between security as a service and taxes, because the construction of efficient state apparatuses - police, justice, education - is not on the timescale of the needs of individuals, and this difference is critical for people who live in FCV countries.

We must not wait for the state to be legitimate for people to pay their taxes. It is the legitimacy of taxation, police or justice, that builds the legitimacy of the state. Where does

e.g. see Cloutier et al. (forthcoming) for Somalia, where security is usually ensured by militia or clan-based security mechanisms. Similarly, in the Sahel, the recent development of communal militias is a non-state local response to provide security. Security is the first-sought priority for local populations, including and sometimes more for local elites who are targeted by violent extremist groups like jihadists. 
this tax legitimacy come from? As Fjeldstad et al. (2018) say, 'the overall challenge is not to tax more, but to tax better, i.e. more consistent, simple, transparent, fair, predictable, efficient and honest'. This policy recommendation is strong but still puts the processes (predictable, transparent, consistent, honest) and the politics (fair) on the same level.

Taxation fairness is critical. Economic actors complain about corruption, regionalism/tribalism and patronage affecting implementation of the law among citizens and over the national territory. Governments may decide to implement less tax pressure in regions affected by rebellions to contain social discontent - for example, exempting former rebels from import taxes on cars they used for combat, to convert them into public transport. This kind of measure generates inequalities before the law and reinforces the diffuse feeling of collusion between authorities and parts of the elite. Equality is at the core of enforcement of the law, including tax law.

Last and not least, bringing politics into taxation is to acknowledge that the administrative weakness of the state cannot be an argument against what has been decided as the fairest option. There is a problem when policies claim to (re)-build the state on the one hand, and, on the other, implement taxation options like VAT or duties on telecommunications only, because these taxes impact all citizens (Matheson and Petit 2017: 24) and are collected by the private sector.

If the legitimacy of taxation is not at the core of the policymaking process we enter a nonvirtuous cycle leading to the emergence of a technical state, whose legitimacy rests only on the fact that it follows international or global technical standards that are sometimes supported by donor agencies. The 'non-political mandate of donors' is laudable and important and necessary, but it should not favour the emergence of 'anti-politics machines' locally (Ferguson 1990).

\subsection{Is local taxation a realistic part of the solution?}

The national state in FCV countries is usually weak, but this varies between national and local levels. Local elites (or citizens and traders) are usually more ready to pay taxes at the local level than at national level. In Somalia, for example, Abshir et al. (2020) and Van den Boogaard et al. (2021) demonstrate that willingness to pay taxes is lowest at the national level and highest at the local level (communities or cities). It was also shown that some cities (at the border with Ethiopia) collect several million US dollars per year when neither the federal member state nor the federal government are present at the border post (World Bank forthcoming). Moreover, local taxation offices may respond with strong mistrust of collection and transfers to the national single Treasury account. The Treasury is normally supposed to redistribute funding nationally. However, due to legitimacy problems, in most cases local elites (and even tax and customs officers) do not trust that any payment to the national level will fund services in their community. Thus, tax transfers to the capital fuel mistrust between the regions and the central state..$^{22}$

However, local taxation is not necessarily the solution for economic development either.

First, it cannot be assumed that local taxation is always better in terms of accountability to the citizens and equity more generally. Indeed, less distance between tax collectors and taxpayers may also facilitate corruption and tax bargaining between elites. Furthermore, it could lead to low collection - and the same absence of redistribution to the poor.

22 This mistrust has often been observed with local traders in Northern Mali or Northern Central Africa Republic, for example. 
Second, taxation at the local level does not necessarily mean the existence of a strong social and fiscal contract. In Somalia, social pressure of the clan for the population to contribute is strong, and also exclusionary in terms of decision-making (Cloutier et al. forthcoming). Ali et al. (2020) demonstrate how British rule largely entrenched the power of chiefs and undermined their accountability to the local population.

Third, one of the main state functions is to facilitate equalisation of resources from the richest parts of the country or society to the poorest segments or parts of the country. Increasing tax competition between towns or regions may increase inequality, or even lead to a country's economic disintegration through a race to the bottom, with even lower revenue collection (World Bank 2020). Beramendi and Rogers (2021) demonstrate that divergence in subnational economies is related to predictable differences in the size of the fiscal state at the sub-national level. Therefore, without equalisation mechanisms, economic and social divergence is likely to be strengthened over time, which leads to pressure on social contracts.

\subsection{Customs revenue, a major source of revenue in FCV countries $^{23}$}

The policy recommendations for developing countries presented in the first section are rather similar in FCV countries - for example, broadening the tax base. However, some tailored pragmatism has emerged recently. In the first instance, easy-to-collect taxes, such as customs revenue, is usually favoured. ${ }^{24}$ Based on its experience in FCV countries, the IMF clearly states that donors 'should not underestimate the importance of customs' (IMF 2017: 43), and advocates for more assistance to be provided to customs administrations. ${ }^{25}$

Indeed, the role of customs administrations in taxation is often blurred by two factors. First, there has been a major doctrinal shift, led by Western countries since 2001, to engage customs on border security within a global policy to combat terrorism, and, in some areas, to contain migration. In the meantime, the traditional customs role of policing goods has been focused on the fight against trafficking of prohibited or highly-taxed goods, like narcotics, weapons, counterfeit and excise goods (cigarettes and alcohol). Consequently, the revenue function of customs has progressively decreased in rich countries - while trade facilitation has remained a major constraint, guiding customs reforms in poor countries since 1994.

The second factor usually blurring the customs role in taxation is purely formal. Official IMF and national budget statistics report national tax figures according to the categories of taxes, regardless of who collects them. However, in most developing countries, customs administrations collect trade-related taxes, sales taxes or value-added taxes (VAT) on imports, and even corporate taxes on exports or port fees in some cases. In FCV countries, revenue collected by customs usually accounts for more than 40 per cent of total tax revenue (see Annex 1).

A major share of collected revenue does not necessarily mean that it contributes to the same level of a fiscal contract. Citizens are taxed indirectly through customs collection and increased consumer goods prices (including food products), and do not necessarily explicitly see their tax contribution.

$24 \quad$ Cogneau et al. (2018) demonstrate that in the first part of the $20^{\text {th }}$ century, a major increase in revenue in Africa was due to intensification of trade taxation: export tax rates roughly doubled between the 1920s and 1950s, while import tax rates nearly tripled in order to be able to expand expenditure. Andersson (2017), using historical data, explains that the prospects of key export commodities explain largely country-specific variation in colonial West Africa.

25 Andersson (2016) shows the fiscal continuity with the colonial period and the importance of trade taxation. On one hand, colonial governments wanted to maximise the return on their investment in tax administration and to allocate scarce funds where they could enhance revenue. On the other hand, colonial authorities were subject to a range of constraining forces that limited their policy space, such as resistance from local populations, a weak economic base, challenging geographies and competing policy objectives. That is why they chose to tax trade, since that was easier than taxing directly local populations who may escape from the French-dominated territories to English-dominated ones. 
Due to the standardisation of procedures by the WCO (the Revised Kyoto Convention), the international convention to classify goods (the Harmonised System), the enforcement of regional tariffs and some off-the-shelf clearance software, customs administrations in FCV countries can quickly start from scratch or re-build their procedures to be effective. However, are customs taxes fair?

First, it is more difficult to evade customs taxes than internal ones - as the old customs adage says, 'goods are the guarantee of taxes'. In this regard, within a context of fragility, customs taxation can be implemented more equally among economic actors than internal taxes.

Second, the computation of customs taxes is relatively basic and uniform, and applies to the same tax base - the value or volume of goods. Governments can therefore apply tax pressure on goods according to their final consumers, deciding to tax some parts of the population more - increasing the transparency of taxation, and making political choices explicit.

Third, traders form the major urban economic elite in FCV countries. Customs taxation is a way to tax them, and to control their enrichment and the development of social inequalities. Informal traders - those who are not the poorest or less organised actors - can also be taxed through customs: some countries decided to levy an import tax that is reimbursed when the trader pays a corporate tax. This is similar to the way the French introduced corporate tax during colonial rule - by first taxing the volume of trade. There is a major political advantage for governments in levying taxes through simple computation rules, to make the political aim of taxation transparent.

These arguments are valuable if the state can control the re-allocation of customs taxes and excises in the final price of goods by the traders. Customs taxation is not exempted from the bargaining process described above. As negotiation is part of taxation, be it in OECD countries or in FCV countries, the fairness question should be the following. Should this negotiation be conducted within the existing asymmetrical relationship between the economic elite, and state officials who do not have any quantitative and transparent analysis - or should the role of state officials be to negotiate well, impose the public good as the major goal, and be monitored for that? The latter is probably the most wishful.

\section{Linking policy and technique: measures applied to customs}

Many of the measures undertaken to implement efficient customs policies in FCV countries have already demonstrated their effectiveness, including, for instance, the computerisation and standardisation of customs procedures, the measurement of customs performance that supports the fight against corruption, trade facilitation, and transparency on tax expenditure. Other changes contribute to reinforcing the legitimacy of the state, including for instance the progressive end of contracts with inspection companies to which governments delegated some key customs tasks, such as estimating value, controlling norms or scanning containers. ${ }^{26}$ This final section proposes to link the political and technical dimensions of

\footnotetext{
26 See https://www.wto.org/english/tratop_e/preship_e/preship_e.htm for more details. In 2013, Customs administrations of West and Central Africa region adopted the Niamey Declaration on provision of inspection services, where they stipulated a readiness to terminate this practice. The WCO supported them by developing Assistance to Members in the Termination of Private Sector Inspection Contacts (see https://www.wcoesarocb.org/wp-content/uploads/2017/03/14-
} 
taxation applied to customs measures in FCV countries, and explore what contributes to their legitimacy. Annex 2 proposes the technical forms of such measures.

\subsection{Use data and develop data analytics to make taxation more transparent}

Data can be used for traditional customs objectives like analysing risk, fighting against fraud, measuring performance and predicting revenue. In FCV countries, the use of data by customs administrations is particularly critical to reduce the asymmetry of information between administration management and field officers, and also between customs and traders, to strengthen the bargaining power of the state with the private sector and consumers more broadly, assess value chains, and adjust taxation according to political objectives.

When customs advocate to increase the tax burden on certain products to reduce pockets of fraud, they face objections that this would increase consumer prices. However, no analysis is conducted concerning the profits of importers and market structure of importing businesses. Customs administrations are usually blind when discussing tax pressure with economic actors - not because they lack data, but because they lack capacity in data analytics and data literacy. Likewise, data is needed to create the conditions for high-level negotiations between governments and the multinational corporations that represent significant contributors, usually with the support of governments of the countries of origin of these multinationals (Durst 2019), or to make more efficient assessment of reforms and revenue projections (Moore et al. 2015). Finally, the use of data, and especially sharing data within society, feeds public debate about tax equity (Mikuriya and Cantens 2020). This goes beyond the simple appeal to morality or citizenship.

However, although customs administrations have been using automated systems since the 1980s, including in many FCV countries, the data is usually not used within the administrations, and even less so outside administrations, with the occasional exception of donors.

The power of data is not related to the level of development. There is no country that is poor in terms of data. There is, proportionally, as much data in FCV countries as in other countries. In FCV countries where customs have an IT clearance system, a customs declaration has around 60 fields of information, and around 300 if we include historical records of the actions on the declaration during its processing by customs. In countries where an IT system is nascent, customs still collect data through the declaration process, ${ }^{27}$ which can be complemented with data collected by the private sector (like port operators, logistics and transport actors), and mirrors data of world exports to the country.

\subsection{Combine anti-fraud and anti-corruption efforts}

Corruption causes a major disruption in equality before the law. Scott (1969) shows how corruption is used as the cheapest way to achieve economic goals by social groups that do not access political decision-makers. In customs administrations corruption is systematically

Guide-on-termination-of-inspection-contracts-FINAL-EN.pdf). Fewer and fewer governments conclude such agreements (see http://www.wcoomd.org/en/media/newsroom/2019/june/wco-participation-in-the-first-african-union-workshop-onpre-shipment-inspections.aspx). Delegating core functions can indeed increase collected revenue in the short term (Yang 2008). However, it does not contribute to state-building in the medium term, and the impact in the long-term is much more debatable.

$27 \quad$ Even in countries impacted by civil war like Libya or Somalia, we observed local IT systems managed by customs. Where the customs information technology (IT) system was damaged or destroyed, like in Mali in 2012, its restoration was considered a priority (https://douanes.gouv.ml/sites/default/files/public/22-\%20Douanes_Int.compressed.pdf). 
associated with fraud, and it hinders reforms. It is cheaper and less risky to bribe customs officials than to by-pass them.

The fights against fraud and corruption should, therefore, be implemented together, which does not happen most of the time. On the one hand, administrations create risk analysis units and train investigators; on the other, they adopt codes of ethics, simplify their regulations and deploy automation. Each of these actions is desirable, but they are seldom coordinated.

In a Sahelian country, despite these measures being in place, a quantified analysis conducted by the authors found that more than 80 per cent of customs inspectors do not engage in any disputes during first-line controls. The fight against fraud brings in less than 0.1 per cent of the revenue collected by the administration, and local officers identify corruption as the major factor explaining why there are so few fraud cases.

Fighting against fraud is primarily a political objective, more than a revenue objective. It will not generate a lot of extra revenue in the short term, but will disrupt corruption chains and their negative impact on equality before the law among economic actors and the relationship between the state and the people. This is a paradigm shift from the one that usually prevails, and puts tax and customs administrations at the forefront of trade facilitation or business climate.

\subsection{Deploy customs in fragile borderlands to restore the presence of the state}

If taxing goods is easier for the state, it is also not difficult for armed groups. Borderlands and points of entry, where there are wealthy actors like traders on whom taxes can be levied, are privileged by armed groups. ${ }^{28}$ Another reason, that is technical, for them to stay in borderlands, is that they can escape the military and police forces by crossing the border, due to difficulties inherent in regional security cooperation and coordination of states across borders.

The security responses to violent extremism and insurgencies are based on a military governance that contains and reduces movement and causes extra costs for traders (Cantens and Raballand 2017).

Despite the fact that customs have a good field knowledge of the border economy, its social and geographical dimensions, they are rarely (not to say never) members of the country's national security committee, bringing together defence and internal security forces.

Cooperation is limited, locally, to customs officials seeking the support of police or military to catch smugglers. ${ }^{29}$ Where customs is absent, other state bodies can perform the customs function - usually the army, which occupies border posts and taxes traders (Cantens and Raballand 2017). This has a negative impact of the state turning into an armed group. The border economy is part of the political strategy of jihadist groups. However, state security policy does not include customs, and taxation and the border economy are not part of the security response to armed groups (Cantens 2019).

Restoring the presence of customs in insecure borderlands is both desirable and feasible. In Niger borderlands, customs offices are connected to the capital and the IT system. This presence may appear as negligible compared to the presence of the military, but it is not.

28 In Niger, since 2018, the median distance to the border of incidents involving jihadist groups is less than $20 \mathrm{~km}$; in Burkina Faso it is less than $50 \mathrm{~km}$, Nigeria less than $60 \mathrm{~km}$ and Chad less than $30 \mathrm{~km}$ (authors' computation based on ACLED data).

29 This cooperation is not for free. Customs usually pay the military on a daily basis, including fuel, for their support. 
Due to their presence, customs collect data (and taxes) on trade flows crossing the borders, despite the presence of jihadist groups. As noted above, the surge of incidents in the Niger borderlands did not cause any decrease in trade flows across insecure areas. This observation can be transposed to almost all insecure areas treated in this paper: the violence of armed groups does not discourage traders. To mitigate the negative impacts of state security responses, there is a need to balance security and economy constraints and adapt security responses to the border economy. Unlike the military, customs are not perceived as a source of recurring violence in remote areas and can then ensure a positive presence of the state at borders, as they encourage and facilitate trade to attract revenue..$^{30}$

Customs are all paramilitary and armed. However, their capacity to patrol and operate in highly insecure areas is low, due to lack of training and heavy equipment. It is not desirable to turn customs into a pure security force. It is better for each state actor at the border to fulfill its mandate. As an example of fostering cooperation between customs and security forces, a regional 'school of borders' is emerging in the Sahel (supported by donors). ${ }^{31}$ Its rationale is to train customs and other security forces together, to reinforce the closeness between security forces and customs - all armed state actors operating in border areas. In this context, customs should be trained in security techniques to interact effectively and securely with the security forces. At the same time, the security forces should be trained to control cross-border flows of goods and people without blocking them. Training customs and other security forces together should be seen as an opportunity for security policies to be mitigated by economic constraints.

\subsection{Technical assistance on the ground}

Technical assistance is not specific to customs or FCV countries. However, due to our experience in FCV countries, we advocate for a specific reflection on this topic.

Technical assistance is often provided remotely, bringing together experts and national officials in a third country or in the field. This is done on an intermittent basis for a limited number of sessions. The COVID-19 pandemic has strengthened the trend toward remote assistance, and it could become a permanent practice. In the IMF's assessment of its own activities in eight FCV countries, two countries in which field missions are prohibited (Afghanistan and Iraq) are those where officials complain the most about technical assistance (Takagi et al. 2018). Complaints include costly trips for national executives to a third country to meet IMF missions, a lack of knowledge of local realities, and inadequate assistance proposals. Conversely, in other countries, such as Bosnia and Herzegovina or Haiti, where the IMF continues to carry out field missions, the national officials interviewed expressed their satisfaction with technical assistance and requested it (Takagi et al. 2018).

Field missions in fragile contexts are costly. However, in most cases, lack of security does not completely prevent access to the field. In Burkina Faso, the Central African Republic, Iraq, Niger, northern Nigeria and Somalia, it was possible to organise advisory and training sessions in the border areas or at ports affected by insecurity (Cantens 2019). US Customs and Border Protection provided long-term technical assistance to Iraqi customs in the field from 2005 to 2011 (US Customs and Border Protection 2011). These examples, as well as

30 In a Niger customs bureau, traders were happy with enclosures set up by the customs office - they could store their goods in them without fear of them being stolen. This simple feature, which should be with the customs bureau rather than military units, encouraged the regional development of the local city market.

31 This project, to 'implant the fiscal and economic software in the security forces', which is led by customs administrations, has been initiated and carried out by one of the authors, with the WCO (WCO 2020). It is developed by the French and Niger customs administrations, the French cooperation and security forces, and is considered a shift in policy response to terrorism in the Sahel. 
those of the IMF, demonstrate that technical assistance on the ground remains possible in FCV countries.

The benefits of providing technical assistance in the field rather than remotely are incommensurable. It is only by observing officials in action that experts can document and understand their constraints. You cannot understand how an administration works by reading its organisational chart and regulatory documents - especially with fragile states, where practices differ significantly from legislation and institutional frameworks. Sharing information about on-the-ground constraints and building relationships are even more crucial in FCV countries, where any change can expose officials to danger, including death threats. Thus, absence from the field undermines the legitimacy of experts.

\section{Concluding remarks}

The concept of the fiscal contract has limits in FCV countries. The tax base is too narrow for an effective tax bargaining process, and it is difficult to generate alliances between the government and some actors versus others. The economic elite has power to refuse or accept a tax measure. Some taxpayers are too large to completely avoid the state, but they do not expect much in exchange for taxation. At most, they can hope to push the state to adopt rules that would be unfavourable to their competitors. However, again, they expect nothing in return for the taxes they pay. They pay a tribute rather than a tax. There is no expected transaction or possible fiscal contract because the timeframes are fundamentally different - the building of efficient state institutions is not on the same timescale as the needs of individuals. What could be acceptable for individuals in a developing country at peace contributing to the construction of the state through taxation, and accepting that its institutions are at a formative stage - is usually not acceptable in a fragile situation where people's lives are threatened.

Moreover, due to legitimacy problems, taxation is focused on the least confrontational instruments - for example, targeting consumers and non-powerful actors by imposing income taxes on individuals. Therefore, they are usually regressive and contribute to an even lower level of tax acceptance. In fragile states, where state legitimacy is in the process of being established, there may be no virtuous cycle between paying taxes and building a state, as in developing countries in general.

Any tax reform in an FCV country should take the political economy and power imbalances between tax collectors and the local population more into consideration. The gap between legislation and reality on the ground is usually very large. Deriving from this, reforms should be realistic: only very limited and gradual changes can be expected in the short-to-medium term, and any technical measure should be analysed through its political meaning.

Moreover, tax compliance and morale are by-products of the legitimacy of the authorities, and the legitimacy of the authorities is a by-product of a tax policy that is perceived as legitimate by the people. A sudden increase in tax pressure is neither sustainable, nor desirable from a political economy perspective. In this regard, 'how to tax' is extremely important, and the fiscal state presence in border regions becomes even more critical for political reasons rather than pure revenue purposes.

Taxes have a transformative power on societies. Thus, the presence of tax administrations is even more necessary in societies affected by conflict and threatened by terrorism. This idea is being increasingly acknowledged. Bräutigam et al. (2008) advocate taxation as a strong 
leverage to improve governance and contribute to state-building, through, among other arguments, generating consent to pay taxes. In addition, one could advocate that more tax enforcement, as evidence of state effort to ensure equality before the law, coupled with more accountability vis-à-vis the citizenry, could have a developmental and transformative impact in the countries that need it most - fragile and conflict-affected countries. 
Annex 1 Share of tax revenue collected by customs

\begin{tabular}{|c|c|c|}
\hline & Share of tax revenue collected by customs & World Customs Organization Report \\
\hline Afghanistan & $42.6 \%$ & $2017-2018$ \\
\hline Bulgaria & $45.4 \%$ & 2018-2019 \\
\hline Burkina Faso & $40.9 \%$ & $2019-2020$ \\
\hline Burundi & $41.3 \%$ & $2019-2020$ \\
\hline Cambodia & $61 \%$ & $2019-2020$ \\
\hline Côte d'Ivoire & $45.6 \%$ & $2019-2020$ \\
\hline Democratic Republic of Congo & $30.9 \%$ & $2019-2020$ \\
\hline Georgia & $44.9 \%$ & 2018-2019 \\
\hline Guatemala & $40 \%$ & $2019-2020$ \\
\hline Guinea & $69.5 \%$ & $2019-2020$ \\
\hline Guinea Bissau & $50.4 \%$ & $2019-2020$ \\
\hline Kosovo & $55.4 \%$ & $2019-2020$ \\
\hline Kyrgyzstan & $40.2 \%$ & $2019-2020$ \\
\hline Liberia & $41.8 \%$ & $2019-2020$ \\
\hline Malawi & $33.2 \%$ & $2018-2019$ \\
\hline Mali & $42 \%$ & $2019-2020$ \\
\hline Moldova & $56.5 \%$ & 2018-2019 \\
\hline Mongolia & $33.3 \%$ & 2018-2019 \\
\hline Morocco & $41 \%$ & 2018-2019 \\
\hline Nepal & $48 \%$ & 2018-2019 \\
\hline North Macedonia & $78.4 \%$ & $2019-2020$ \\
\hline Pakistan & $46.2 \%$ & $2019-2020$ \\
\hline Palestine & $73.8 \%$ & $2019-2020$ \\
\hline Paraguay & $47.7 \%$ & $2019-2020$ \\
\hline Rwanda & $31.1 \%$ & 2018-2019 \\
\hline Senegal & $35 \%$ & 2018-2019 \\
\hline Serbia & $51.6 \%$ & $2019-2020$ \\
\hline Slovakia & $42 \%$ & 2018-2019 \\
\hline Sri Lanka & $45.3 \%$ & $2019-2020$ \\
\hline Suriname & $43 \%$ & $2019-2020$ \\
\hline Tanzania & $39.8 \%$ & 2019-2020 \\
\hline Togo & $55.7 \%$ & 2019-2020 \\
\hline Uganda & $41.4 \%$ & 2019-2020 \\
\hline Ukraine & $37 \%$ & $2019-2020$ \\
\hline Zambia & $34.3 \%$ & 2019-2020 \\
\hline Zimbabwe & $37.4 \%$ & $2019-2020$ \\
\hline
\end{tabular}




\section{Annex 2 Fighting against fraud and corruption - some technical measures applied to customs}

\begin{tabular}{|l|l|}
\hline $\begin{array}{l}\text { Train officials in control } \\
\text { techniques }\end{array}$ & $\begin{array}{l}\text { Training should focus concretely on control techniques, and not serve as a reminder } \\
\text { about the basics of tax or customs laws, as is often the case. In all countries, there are } \\
\text { national experts competent to train the younger generation of officers. Assistance } \\
\text { should focus on investigation techniques. }\end{array}$ \\
\hline $\begin{array}{l}\text { Ensure the existence of an } \\
\text { incentive framework for controls, } \\
\text { including effective } \\
\text { implementation }\end{array}$ & $\begin{array}{l}\text { In most countries, the legal framework includes the payment of litigation bonuses, both } \\
\text { individual and collective, to customs officials. }\end{array}$ \\
\hline $\begin{array}{l}\text { Measure individual performance } \\
\text { of officials performing control } \\
\text { missions }\end{array}$ & $\begin{array}{l}\text { Experience has shown that some individual practices can quickly improve the situation, } \\
\text { provided they are quantified and that indicators are shared internally and with the } \\
\text { political authority and trade and transport stakeholders (Cantens et al. 2011; Chalendard } \\
\text { et al. 2019). }\end{array}$ \\
\hline $\begin{array}{l}\text { Create intelligence units and } \\
\text { databases recording fraud cases }\end{array}$ & $\begin{array}{l}\text { Customs intelligence is often a particularly neglected area. Officers mainly rely on } \\
\text { informants. This is usually effective, but insufficient because of a high dependence on } \\
\text { individual relationships with informants, the risk of links between informants and } \\
\text { officials, and the lack of consolidation of information. In many administrations, there is } \\
\text { no database concerning disputes and seizures, as well as no operational intelligence } \\
\text { unit. }\end{array}$ \\
\hline $\begin{array}{l}\text { Develop techniques to detect } \\
\text { customs clearance anomalies }\end{array}$ & $\begin{array}{l}\text { Differences in tax pressure among offices or in the application of regulations between } \\
\text { administrative regions. Regarding customs, it is not uncommon to find differences in tax } \\
\text { pressure depending on offices for identical goods imported from the same source } \\
\text { countries by the same importers (Raballand et al. 2017). }\end{array}$ \\
\hline $\begin{array}{l}\text { Develop a geographical } \\
\text { approach in the fight against } \\
\text { fraud }\end{array}$ & $\begin{array}{l}\text { In order to optimise the presence of the state - in particular customs posts and patrols in } \\
\text { border areas, where the presence of the state is challenged by armed groups. }\end{array}$ \\
\hline
\end{tabular}




\section{References}

Abshir, S., Abdirahman, K. and Stogdon, H. (2020) Tax And The State In Somalia: Understanding Domestic Revenue Mobilization, Rift Valley Institute Briefing Paper

Acemoglu, D. and Robinson, J. (2012) Why Nations Fail: The Origins of Power, Prosperity, and Poverty, New York: Crown Business

Akitoby B., Honda J. and Primus K. (2020) Tax Revenues in Fragile and Conflict-Affected States - Why Are They Low and How Can We Raise Them?, IMF Working Paper $\mathrm{WP} / 20 / 143$

Ali, M., Fjeldstad, O-H. and Shifa, A. (2020) 'European colonization and the corruption of local elites: The case of chiefs in Africa', Journal of Economic Behavior \& Organization 179: $80-100$

Andersson. J. (2017) 'Long-Term Dynamics of the State in Francophone West Africa: Fiscal Capacity Pathways 1850-2010', Economic History of Developing Regions 32:1

— (2016) 'Keeping the gates: The colonial customs administration in French West Africa', paper presented at 'VI Annual Meeting of the African Economic History Network', held at the University of Sussex, Brighton, UK 21-22 October 2016

- (2015) Fiscal capacity and state formation in francophone West Africa 1850-2010, African Economic History Network Working Paper 23

Ayadi, L., Benjamin, N, Bensassi, S and Raballand, G. (2013) 'Estimating informal trade across Tunisia's land borders' World Bank Policy Research Working Paper 6731

Beramendi, P. and Rogers, M. (2021) 'Disparate geography and the origins of tax capacity', Review of International Organizations 16: 213-237

Besley, T. and Persson, T. (2009) 'The Origins of State Capacity: Property Rights, Taxation, and Politics', American Economic Review 99(4): 1218-44

Blannin, P. (2017) 'Islamic State's Financing: Sources, Methods and Utilisation', Counter Terrorist Trends and Analyses 9(5): 13-22

Blundo, G. (2011) 'Une administration à deux vitesses. Projets de développement et construction de l'État au Sahel', Cahiers d'études africaines 51(202-203): 427-452

_ and Glasman, J. (2013), 'Introduction: Bureaucrats in uniform', Sociologus 63(1/2): 1-9

Bräutigam, D., Fjeldstad, O-H. and Moore, M. (2008) Taxation and State-Building in Developing Countries: Capacity and Consent, Cambridge: Cambridge University Press

Cantens, T. (2019) 'Fragile Borders in Sub-Saharan Africa: the Nexus Between Economy and Security at Borders', AntiAtlas Journal (3), Aix-Marseille University, IMERA

_ (2013) 'Other People's Money and Goods: The Relationship Between customs Officers and Users in Some Countries of Sub-Saharan Francophone Africa', Sociologus: 37-58 
(2012) 'Is it possible to reform a customs administration? The role of the customs elite on the reform process in Cameroon', in A. Amsden, A. DiCaprio and J. Robinson, The role of elites in economic development, Oxford: Oxford University Press

and Raballand, G. (2017) Cross-border trade, insecurity and the role of customs: Some lessons from six field studies in (post-) conflict regions, ICTD Working Paper 67, Brighton: Institute of Development Studies

(2016) Fragile Borders: rethinking borders and insecurity in Northern Mali, Geneva: Global Initiative Against Transnational Organized Crime

and Bilangna, S. (2011) 'Reforming Customs by Measuring Performance: a Cameroon Case Study', in O. Cadot, A. Fernandes, J. Gourdon and A. Matto (eds), Where to Spend the Next Million? Applying Impact Evaluation to Trade Assistance, Center of Economic Policy Research

Chalendard, C., Raballand, G. and Rakotoarisoa, A. (2019) 'The use of detailed statistical data in customs reforms: the case of Madagascar', Development Policy Review 37(4): 546-563

Chambas, G. (2005) 'TVA et transition fiscale en Afrique: les nouveaux enjeux', Afrique contemporaine (3): 181-194

Clastres, P. (1974) La société contre l'Etat, Editions de Minuit

Cloutier, M., Hassan, H., Isser, D. and Raballand, G. (forthcoming) Understanding Somalia's Social Contract and State-Building Efforts: Consequences for Donor Interventions, mimeo

Cogneau, D., Dupraz, Y. and Mesplé-Somps, S. (2018) African states and development in historical perspective: Colonial public finances in British and French West, PSE Working Paper

Day, A. (2020) Hybrid Conflict, Hybrid Peace: How Militias and Paramilitary Groups Shape Post-conflict Transitions, New York: United Nations University

Drummond, P., Daal, W., Srivastava, N. and Oliveira, L. (2012) Mobilizing Revenue in SubSaharan Africa: Empirical Norms and Key Determinants, Working Paper 12/108, Washington DC: IMF

Dupée, M. (2017) 'The Taliban Stones Commission and the Insurgent Windfall from Illegal Mining', CTC Sentinel 10(3): 31-35

Durst, M. (2019) Taxing Multinational Business in Lower-Income Countries: Economics, Politics and Social Responsibility, Institute of Development Studies, International Centre for Tax and Development

Fairfield, T. (2015) Private Wealth and Public Revenue in Latin America: Business Power and Tax Politics, Cambridge University Press

Ferguson, James (1990) The Anti-Politics Machine: 'Development', Depoliticization and Bureaucratic Power in Lesotho, Cambridge: Cambridge University Press 
Fjeldstad, O-H., Bøås, M., Bjørkheim, J. and Kvamme, F. (2018) Building Tax Systems in Fragile States. Challenges, Achievements and Policy Recommendations, CMI Report R 2018:03, Bergen: Chr. Michelsen Institute

IMF (2017) Building Fiscal Capacity in Fragile States, Policy Paper, Washington DC: IMF

Isar, S. (2020) Taxation, the prerequisite of state-building, an overview of tax system in Afghanistan, Afghanistan Research and Evaluation Unit Policy Note

Jin, G. (2018) 'Circle of Fortune: The Long-Term Impact of Western Customs Institutions in China', in Annual Conference 2018 (Freiburg, Breisgau): Digital Economy (No. 181605), Verein für Socialpolitik/German Economic Association

Kalyundu, G. and Norregaard, J. (2020) Designing Federal Tax Policy for Enhanced Domestic Revenue Mobilization, IMF Technical Report, Washington DC: IMF

Lefebvre, C. (2015) 'Comment occuper les territoires? (1900-1930)', in Frontières de sable, frontières de papier : Histoire de territoires et de frontières, du jihad de Sokoto à la colonisation française du Niger, $X I X^{e}-X X^{e}$ siècles, Éditions de la Sorbonne, doi :10.4000/books.psorbonne

Levi, M. (2003) 'The Transformation of a Skeptic: What Nonexperimentalists can Learn from Experimentalists', in E. Ostrom and J. Walker (eds) Trust and Reciprocity, New York: Russell Sage

Macedo, L. (2011) 'Large Traders' Customs Units', World Customs Journal 5(1): 63-71

Mansour M. and Schneider J.-L. (2019) How to Design Tax Policy in Fragile States, How To Notes 19/04, Washington DC: IMF

Matheson, T. and Petit, P. (2017) Taxing telecommunications in developing countries, IMF Working Paper 17/247

Mikuriya, K. and Cantens, T. (2020) 'If algorithms dream of Customs, do customs officials dream of algorithms? A manifesto for data mobilization in Customs', World Customs Journal, 14(2): 3-22

Moore, M. (2020) What is Wrong with African Tax Administration?, ICTD Working Paper 111, Brighton: Institute of Development Studies

— Fjeldstad, O. H., Isaksen, J., LundstøI, O., McCluskey, R. and Prichard, W. (2015) Building tax capacity in developing countries, IDS Policy Briefing 96, Brighton: Institute of Development Studies

OECD (2014) Citizen-State relations. Improving governance through tax reforms, Paris: OECD

_ (2009) Engaging with high net worth individuals on tax compliance, Paris: OECD

Peters, G. (2009) How opium profits the Taliban, Peaceworks No. 62, Washington DC: United States Institute of Peace 
Prichard, W. (2019) 'Tax, Politics, and the Social Contract in Africa', Oxford Research Encyclopedia of Politics May 2019 Update

Raballand, G., Chalendard, C., Fernandes, A., Mattoo, A and Rijkers, B. (2017) Customs Reform and Performance Contracts: Early Results from Madagascar, World Bank Governance Note 2, Washington: World Bank

Scott, J. (2009) The Art of Not Being Governed: An Anarchist History of Upland Southeast Asia, Yale University Press

_ (1969) 'The analysis of corruption in developing nations', Comparative studies in society and history 11(3): 315-341

Takagi, S., Donovan, D., Momani, B., Perez, L., de Las Casas, M. and Pisa, M. (2018) The IMF and Fragile States: Eight Selected Country Cases, Background Document No. BD/18-02/01, Washington: IMF

Tilly, C. (2009) 'Foreword', in I. Martin, A. Mehrotra and M. Prasad (eds.) The new fiscal sociology: taxation in comparative and historical perspective, Cambridge University Press

US Customs and Border Protection (2011) 'A powerful presence in Iraq', Frontline 5(1): 8-15

Van den Boogaard, V. and Santoro, F. (2021) Explaining Informal Taxation and Revenue Generation: Evidence from south-central Somalia, ICTD Working Paper 118, Brighton: Institute of Development Studies

Vehorn, C. (2011) 'Fiscal Adjustment in Developing Countries through Tax Administration Reform', The Journal of Developing Areas 45: 323-338

World Bank (forthcoming) Somalia - Country Economic Memorandum, Washington DC: World Bank

- (2020) Domestic Resource Mobilization in Somalia, Public Expenditure Review Module, Washington DC: World Bank

WCO (2020) 'WCO supports the Pau Declaration by G5 Sahel countries' Heads of State and the French President', available at < http://www.wcoomd.org/en/media/newsroom/2020/january/world-customs-organizationsupports-the-pau-declaration.aspx >, accessed on 15 March 2021

Yang, D. (2008) 'Integrity for hire: an analysis of a widespread customs reform', The Journal of Law and Economics 51(1): 25-57 